\title{
INTRODUCING SCIENTIFIC WRITING AS MANDATORY TOPIC IN BACHELOR NURSING PROGRAM - EXPERIENCE OF THE UNIVERSITY OF DUBROVNIK, CROATIA
}

\author{
Mihaela Zidarić ${ }^{1}$, Višnja Vičić-Hudorović ${ }^{2}$ and Narcis Hudorović ${ }^{3}$ \\ ${ }^{1}$ Jordanovac Clinical Department of Pulmonology, Zagreb University Hospital Center; \\ ${ }^{2}$ Vrapče Nursing School; ${ }^{3}$ Department of Vascular Surgery, Sestre milosrdnice University Hospital Center, \\ Zagreb, Croatia
}

\begin{abstract}
SUMMARY - One of the methods that have been used to encourage student reflection skills is scientific writing. The purpose of this article is to discuss implementation of obligatory study topic with the main objective to increase the skills of scientific writing among students of Bachelor Nursing Curriculum and its relation to scientific publishing volume of Bachelor degree students from the University of Dubrovnik. By searching the local rank database called HRČAK, data were collected on publication volume of the Bachelor course students at the University of Dubrovnik from 2010 to 2014. Articles published in the Croatian medical journals in Croatian language were identified. Sixtysix students published 35 articles, alone or with co-authors. Two (6\%) articles were written by a single author. Among co-authors from the nursing profession, those with associate degree in nursing (20\%) predominated, followed by medical doctors and anthropologists (25\%). The total number of authors was 95, and the share of papers published in Croatian language was 100\%. The body of published articles increased from 2012 to 2013 by 14\%, and then from 2013 to 2014 by 113\%. For future investigations, closer insight into novel approaches is needed to encourage nursing students to increase their scientific productivity, especially in English language. In order to enhance international visibility of Croatian nursing authors, academic members of the Croatian scientific nursing community should find additional tools to upgrade scientific productivity of the Croatian nursing authors.
\end{abstract}

Key words: Research; Writing; Nursing - education; Publications; Education, Nursing, Baccalaureate; Databases as topic; Croatia

\section{Introduction}

The nursing profession in Croatia recognizes traditional route to become a doctoral degree nurse $(\mathrm{PhD})$ : Associate Degree in Nursing (AD) programs to Bachelor of Science in Nursing (BSN) program and a diploma program offered at five-year colleges and universities, Master of Science in Nursing (MSN) offer-

Correspondence to: Narcis Hudorovic, $M D, P h D$, Department of Vascular Surgery, Sestre milosrdnice University Hospital Center, Vinogradska c. 29, HR-10000 Zagreb, Croatia

E-mail: narcis.hudorovic@zg.t-com.hr

Received January 5, 2015, accepted April 9, 2015 ing two-year diploma course, and doctoral programs offering three-year program at senior colleges and universities ${ }^{1}$. Graduates from all these programs sit for the Croatian Nursing Council (CNC) examination for registered nurse $(\mathrm{RNs})$ certificate, which measures minimum technical competency for the nursing practice level.

Currently, 4086 nurses are enrolled in $14 \mathrm{RN}$ to $\mathrm{BSN}$ and two BSN to $\mathrm{PhD}$ programs offered at high schools and universities throughout Croatia. From 2007 to 2013, enrollments in AD to baccalaureate programs increased by $11 \%$ as the fifth consecutive year of enrollment increase. 
Scientific writing techniques are not currently part of the standard 16 Bachelor nurse education curricula in Croatia. As a result, BSN students are not able to properly incorporate scientific writing skills into everyday practice, making them less competitive with medical doctors, and more importantly, with members of the international nursing communities ${ }^{2-4}$. According to the rules of the Croatian colleges and universities, when nurses have acquired the BSN level of education, they must be able of independent publication of scientific articles ${ }^{1}$.

According to previous studies stating that students who published articles prior to acquiring the degree must be considered as having proved their scientific potential ${ }^{5-7}$, we conclude that BSN students have to be trained in publishing scientific articles during the study. In order to overcome a number of impediments that BSN students are facing while looking how to get engaged in scientific writing ${ }^{8-11}$, the University in $\mathrm{Du}-$ brovnik (UNIDU), Croatia, included scientific writing as a mandatory course in the Bachelor nurse curriculum five years ago. The aim of the present study was to determine the number and relationship of the articles published by all UNIDU BSN students of the last six academic generations in Croatian scientific journals before and after the introduction of scientific writing as a mandatory course in the baccalaureate program.

\section{Material and Methods}

The study sample included 149 BSN students at UNIDU from the beginning of the BSN program in 2007 until 2013 (six academic generations). Data were collected on the following parameters: authors (number, gender, level of education and academic title); article type (original research, technical, review and brief communication); and cited references (number and type). Bibliometric analysis was performed using the local database HRČAK. No ethical approval was needed.

\section{Collection of bibliographic data}

In order to improve accessibility and visibility of Croatian journals, the Croatian Information and Documentation Society launched the HRČAK digital platform in 2005. HRČAK means hamster in Croatian. It is a free platform for Croatian open-access scholarly journals, which has expanded its archives from the initial three to the current 356 periodicals, with more than 111,000 articles listed, including 105,873 full-text items for open access ${ }^{12,13}$. More than half of the archived journals in the field of science, technology and medicine are published in English only, and the majority of journals (76\%) have international editorial boards ${ }^{13}$.

Topics covered by the portal range from biomedicine and natural sciences to humanities and social sciences. The readers and authors can easily find links to the journals and articles of interest by searching in alphabetical order or by scientific area ${ }^{14}$. HRČAK also allows to search within the journal papers by author, title and keywords. The portal calculates detailed statistics for indexed journals, which is updated at the beginning of each month. Statistics cover journals webpage visits (home page, issues, single article and bibliographic records) and full-text (PDF) downloads. Interested readers are referred to the respective website for further information (www.hrcak.srce.hr).

Official lists of names of the six generations of BSN students were obtained from the UNIDU official records. Document (article type), Author and Affiliation search was used as a searching tool.

First, author index in HRČAK was searched by each of 149 names of BSN students. From the results obtained, papers published in Croatian language were singled out first. For titles of these articles in English, there is a note that full text is published in Croatian language.

Second, we wanted to find out whether introducing the BSN program at UNIDU had reflected in the number of publications (co)authored by nurses. More specifically, we investigated the structure of graduate education of all authors of published articles where a nurse was one of the co-authors.

\section{Results}

The BSN students published articles in four Croatian scientific journals, as follows: Nursing Education Magazine; Croatian Journal of Public Health; Child, Kindergarten and Family Journal; and Sestrinski glasnik/Nursing Journal. The analyzed material included a total of 28 volumes, 83 issues, 644 articles and 2514 pages. There was no article published in international journals. 
Table 1. Croatian scientific journals in which University of Dubrovnik Bachelor of Science in Nursing (BSN) students published their articles

\begin{tabular}{|l|c|c|}
\hline $\begin{array}{l}\text { Journal title/ISSN/number of analyzed volumes, } \\
\text { issues and articles }\end{array}$ & $\begin{array}{c}\text { Number of published articles } \\
\text { by BSN candidates } \\
\text { (total number of cited references) }\end{array}$ & Percentage \\
\hline $\begin{array}{l}\text { Nursing Education Magazine } \\
\text { (1334-7551) (7 Vol.; 7 No.11; articles 21; pages 130) }\end{array}$ & 2 & $10 \%$ \\
Croatian Journal for Public Health & $(13)$ & $4 \%$ \\
(1845-3082) (7 Vol.; 22 No.; articles 252; pages 1194) & 10 & $2 \%$ \\
Child, Kindergarten, Family & $(78)$ & $7 \%$ \\
(0353-9504) (7 Vol.; 24 No.; articles 49; pages 319) & $(0)$ & 72 \\
Sestrinski glasnik/Nursing Journal & 22 & \\
(1331-7563) (7 Vol.; 26 No.; articles 322; pages 871) & $(172)$ & \\
\hline
\end{tabular}

\section{Journal analysis}

Thirty-five articles were published in 4 journals, and all articles were published in Croatian language. Most articles were published in Sestrinski glasnik/ Nursing Journal (Table 1). In order to analyze scientific fields of the journals where the articles appeared, we used the list created by Popescu ${ }^{15}$. Two journal titles had one discipline attached and another two journals had two disciplines from social sciences (Anthropology and Public Health). Journal titles, International Standard Serial Number (ISSN), number of volumes, issues, articles, number of pages and cited references analyzed are shown in Table 1.

\section{Address analysis}

The main problem in identifying a scientific institution is its address, depending on the structure of the address itself. In the HRČAK database, addresses of all co-authors are listed on the top of the article. In 35 analyzed articles, there were 60 addresses of institutions. Detailed check of each address showed one of the authors coming from UNIDU to be definitely confirmed in 48 cases, whereas the remaining 12 author addresses were from different institutions.

\section{Address structure}

The UNIDU affiliation was stated in 48 (80\%) addresses, whereas $12(20 \%)$ addresses did not mention university affiliation at all. Due to partial employment in different institutions, 14 addresses stated two institutions. The same authors were found sometimes to state one and sometimes another institution.

\section{Author analysis}

A total of 95 authors cooperated on 35 published articles, and total number was achieved by adding the number of authors per article. The analysis confirmed that most of the articles had three or more authors $(n=27 ; 77 \%)$, followed by two authors $(n=6 ; 17 \%)$, and one author $(\mathrm{n}=2 ; 6 \%)$. The maximum number of authors in one article was ten and total number of authors was 95 . The mean number of authors was 4.4 (Tables 2 and 3).

\section{Co-authorship}

All 35 articles had at least one author from UNIDU, and so did 3 single-author articles. Analysis of each article revealed often co-authorship inside the UNIDU (32 articles; 91\%). Thirty-one (89\%) articles were published in cooperation with scientists from other Croatian institutions. There was no cooperation with scientists from foreign scientific institutions. The data collected revealed most of the students to come from clinical environment. The articles were written by $66 \mathrm{BSN}$ students/authors, $88 \%$ of them female. All coauthors (100\%) were from Croatia, indicating inadequate international collaboration. Less than one-quarter (23\%) of the UNIDU BSN students having published articles before or after graduation were listed without a title indicating their undergraduate education.

Among 50 co-authors from the nursing profession there were 10 authors with $\mathrm{AD}, 37$ with Bachelor degree, two with MS degree and one with PhD. Only three co-authors were from medical profession (MD), 
Table 2. Articles published by UNIDU BSN students in the 2010-2014 period in Sestrinski glasnik/Nursing Journal (SG/NJ), official Journal of the Croatian Nursing Association as the only professional journal in the field of nursing in Croatia

\begin{tabular}{|c|c|c|c|c|}
\hline $\begin{array}{l}\text { Sestrinski glasnik/Nursing } \\
\text { Journal (year; volume; pages) }\end{array}$ & $\begin{array}{l}\text { Article } \\
\text { category }\end{array}$ & $1^{\text {st }}$ author & $\begin{array}{l}\text { Number and category } \\
\text { of co-authors }\end{array}$ & Number of references \\
\hline SG/NJ 2011;16 (1-2):8-10 & $\mathrm{OA}$ & BSN & $1 \mathrm{MD} \mathrm{PhD}$ & 2 (1 OA, 1 web resource) \\
\hline SG/NJ 2011;16 (3):90-95 & $\mathrm{OA}$ & $\mathrm{BSN}$ & $\begin{array}{c}4 \text { BSN } \\
1 \mathrm{PhD} \text { Anthropology }\end{array}$ & 5 (3 OA, 2 web resources) \\
\hline SG/NJ 2012;17 (1):28-33 & $\mathrm{OA}$ & BSN & $\begin{array}{c}1 \mathrm{BSN} \\
1 \mathrm{MD} \mathrm{PhD}\end{array}$ & 12 (11 OA, 1 book chapter) \\
\hline SG/NJ 2012;17 (3):169-174 & $\mathrm{OA}$ & $\mathrm{BSN}$ & $\begin{array}{l}1 \mathrm{MD} \mathrm{PhD} \\
1 \text { Professor }\end{array}$ & 14 (7 OA, 7 book chapter) \\
\hline SG/NJ 2012;17 (3):174-177 & $\mathrm{OA}$ & BSN & $\begin{array}{l}1 \mathrm{MD} \mathrm{PhD} \\
1 \text { Professor }\end{array}$ & $\begin{array}{l}7 \text { (1 OA, } 5 \text { book chapter, } \\
1 \text { web resource) }\end{array}$ \\
\hline SG/NJ 2013;18 (1):12-17 & $\mathrm{OA}$ & BSN & 2 PhD Anthropology & $\begin{array}{c}5 \text { (1 PhD thesis, } 2 \text { book chapters, } \\
2 \text { abstracts) }\end{array}$ \\
\hline SG/NJ 2013;18 (1):24-28 & $\mathrm{OA}$ & $\mathrm{BSN}$ & $\begin{array}{c}1 \mathrm{BSN} \\
1 \mathrm{Professor} \\
1 \mathrm{MD} \mathrm{PhD}\end{array}$ & $\begin{array}{l}11 \text { (7 OA, } 3 \text { book chapters, } \\
1 \text { PhD thesis) }\end{array}$ \\
\hline SG/NJ 2013;18 (2):113-118 & $\mathrm{OA}$ & BSN & $\begin{array}{c}1 \mathrm{BSN} \\
1 \mathrm{PhD} \text { Anthropology }\end{array}$ & 12 (1 book chapter, 11 web resources) \\
\hline SG/NJ 2013;18 (3):174-181 & $\mathrm{OA}$ & BSN & 1 PhD Anthropology & 9 (7 book chapters, 2 web resources) \\
\hline SG/NJ 2014;19 (1):12-16 & $\mathrm{OA}$ & BSN & $1 \mathrm{MD} \mathrm{PhD}$ & $\begin{array}{c}19 \text { (5 OA, } 8 \text { books, } 2 \text { book chapters, } \\
4 \text { web resources) }\end{array}$ \\
\hline SG/NJ 2014;19 (1):22-25 & $\mathrm{OA}$ & $\mathrm{BSN}$ & $\begin{array}{c}3 \mathrm{BSN} \\
1 \mathrm{MD} \mathrm{PhD}\end{array}$ & $\begin{array}{l}9 \text { (4 OA, } 3 \text { Review article; } \\
2 \text { book chapters) }\end{array}$ \\
\hline SG/NJ 2014;19 (1):30-41 & $\mathrm{OA}$ & BSN & $1 \mathrm{BSN}$ & $\begin{array}{c}11 \text { (7 OA 7,2 BC, } 1 \text { book chapter; } \\
1 \text { PhD thesis) }\end{array}$ \\
\hline SG/NJ 2014;19 (1):66-67 & $\mathrm{BC}$ & BSN & & $3(3 \mathrm{OA})$ \\
\hline SG/NJ 2014;19 (1):63-65 & $\mathrm{BC}$ & $\mathrm{BSN}$ & $\mathrm{AD}$ & 14 (OA 8, 6 book chapters) \\
\hline SG/NJ 2014;19 (2):89-94 & $\mathrm{OA}$ & BSN & $\begin{array}{c}1 \text { BSN } \\
4 \mathrm{PhD} \text { Anthropology }\end{array}$ & $\begin{array}{c}22 \text { (4 OA, } 4 \text { review article, } 6 \text { book } \\
\text { chapters, } 2 \mathrm{PhD} \text { thesis, } 6 \text { web resources })\end{array}$ \\
\hline SG/NJ 2014;19 (2):122-126 & $\mathrm{OA}$ & BSN & $1 \mathrm{MD} \mathrm{PhD}$ & 11 (9 OA, 2 book chapters) \\
\hline SG/NJ 2014;19 (2):155-157 & $\mathrm{BC}$ & $\mathrm{BSN}$ & & $\begin{array}{c}6 \text { (3 OA, } 2 \text { book chapters, } \\
1 \text { web resource) }\end{array}$ \\
\hline SG/NJ 2014;19 (2):158-161 & $\mathrm{BC}$ & BSN & $\begin{array}{c}3 \mathrm{BSN} \\
1 \mathrm{MD} \mathrm{PhD}\end{array}$ & $\begin{array}{l}3 \text { (1 OA, } 1 \text { book chapter, } \\
1 \text { web resource) }\end{array}$ \\
\hline SG/NJ 2014;19 (3):189-195 & $\mathrm{BC}$ & $\mathrm{BSN}$ & & $\begin{array}{c}15 \text { (4 OA, } 1 \text { BC, } 6 \text { Review, } \\
3 \text { book chapters } 1 \text { web resource) }\end{array}$ \\
\hline SG/NJ 2014;19 (3):183-188 & $\mathrm{OA}$ & BSN & MD PhD & $\begin{array}{l}18 \text { (1 OA, } 10 \text { book chapters, } \\
1 \text { PhD thesis, } 6 \text { web resources) }\end{array}$ \\
\hline SG/NJ 2014;19 (3):211-219 & $\mathrm{OA}$ & BSN & $\begin{array}{l}1 \mathrm{MD} \mathrm{PhD} \\
1 \mathrm{PhD} \text { Nurse }\end{array}$ & $\begin{array}{c}11 \text { ( } 2 \text { OA, } 7 \text { book chapters, } \\
2 \text { web resources) }\end{array}$ \\
\hline SG/NJ 2014;19 (3):239-241 & $\mathrm{BC}$ & $\mathrm{BSN}$ & $\begin{array}{c}2 \mathrm{BSN} \\
1 \mathrm{MD} \mathrm{PhD}\end{array}$ & 8 (6 OA, 2 book chapters) \\
\hline Total & $\begin{array}{l}\text { OA } 16 \\
\text { BC } 6\end{array}$ & BSN 22 & $\begin{array}{c}22 \mathrm{BSN} \\
3 \mathrm{MD} \mathrm{PhD} \\
3 \mathrm{PhD} \text { Anthropology } \\
1 \text { Professor } \\
1 \mathrm{PhD} \text { Nurse }\end{array}$ & 224 \\
\hline
\end{tabular}

UNIDU BSN = University of Dubrovnik Bachelor of Science in Nursing; BSN = Bachelor of Science in Nursing; OA = original article; $\mathrm{BC}=$ brief communication; $\mathrm{MD}=$ Medical Doctor; $\mathrm{BA}=$ baccalaureate; $\mathrm{MS}=$ Master of Science $\mathrm{PhD}=$ Doctor of Philosophy 
Table 3. Articles published in the 2010-2014 period by University of Dubrovnik Bachelor of Science in Nursing students and co-author level of education in Croatian journals the aims and scopes of which are not primarily related to nursing profession

\begin{tabular}{|c|c|c|c|c|}
\hline $\begin{array}{l}\text { Journal title abbreviation } \\
\text { (year; volume; pages) }\end{array}$ & $\begin{array}{l}\text { Article } \\
\text { category }\end{array}$ & First author & $\begin{array}{c}\text { Number and category } \\
\text { of co-authors }\end{array}$ & Number of references \\
\hline CJFHP 2012; 8 (29):35-48 & OA & $\mathrm{BSN}$ & $\begin{array}{c}4 \text { BSN } \\
1 \mathrm{PhD} \text { Anthropology }\end{array}$ & $\begin{array}{c}10 \text { (3 OA, } 7 \text { book } \\
\text { chapters) }\end{array}$ \\
\hline CJFHP 2012; 8 (29):49-57 & $\mathrm{OA}$ & $\begin{array}{c}1 \mathrm{PhD} \\
\text { Anthropology }\end{array}$ & $5 \mathrm{BSN}$ & $\begin{array}{c}7 \text { (4 OA, } 2 \text { book } \\
\text { chapters, } 1 \text { PhD thesis) }\end{array}$ \\
\hline CJFHP 2012; 8 (31):90-95 & $\mathrm{OA}$ & BSN & $\begin{array}{c}1 \text { MS Professor } \\
1 \text { PhD Anthropology }\end{array}$ & 4 (4 book chapters) \\
\hline CJFHP 2012; 8 (32):137-142 & $\mathrm{OA}$ & $\mathrm{BSN}$ & $\begin{array}{c}1 \text { PhD Anthropology } \\
1 \text { MS Professor }\end{array}$ & $\begin{array}{l}8 \text { (6 book chapters, } \\
2 \text { PhD theses) }\end{array}$ \\
\hline CJFHP 2013; 9 (34):33-40 & $\mathrm{OA}$ & $\mathrm{BSN}$ & $1 \mathrm{PhD}$ Anthropology & $\begin{array}{c}14 \text { (3 OA, } 9 \text { book } \\
\text { chapters, } 2 \text { PhD thesis) }\end{array}$ \\
\hline CJFHP 2013; 9 (35):148-157 & $\mathrm{OA}$ & $\mathrm{BSN}$ & $1 \mathrm{PhD}$ Anthropology & $\begin{array}{l}9 \text { (7 book chapters, } \\
2 \text { web resources) }\end{array}$ \\
\hline CJFHP 2013; 9 (33):247-268 & $\mathrm{OA}$ & BSN & $\begin{array}{c}1 \text { PhD Anthropology } \\
1 \text { MS Professor } \\
1 \text { MS Nurse }\end{array}$ & $\begin{array}{c}5 \text { (1 OA, } 4 \text { book } \\
\text { chapters) }\end{array}$ \\
\hline CJFHP 2013; 9 (33):283-298 & $\mathrm{OA}$ & $\mathrm{BSN}$ & $\begin{array}{c}1 \text { BSN } \\
1 \text { PhD Anthropology } \\
1 \text { MS Nurse }\end{array}$ & $\begin{array}{l}5 \text { ( } 4 \text { book chapters, } \\
1 \text { web resource) }\end{array}$ \\
\hline CJFHP 2014; 10 (37):98-109 & $\mathrm{OA}$ & BSN & $\begin{array}{c}1 \text { MS Nurse } \\
1 \text { PhD Anthropology }\end{array}$ & $\begin{array}{c}8 \text { (1 OA, } 6 \text { book } \\
\text { chapters, } 1 \text { PhD thesis) }\end{array}$ \\
\hline CJFHP 2014; 10 (38):121-188 & $\mathrm{OA}$ & $\mathrm{BSN}$ & $\begin{array}{c}2 \text { BSN } \\
1 \mathrm{PhD} \text { Anthropology }\end{array}$ & $\begin{array}{c}8(1 \mathrm{OA}, 6 \text { book } \\
\text { chapters, } 1 \text { web resource })\end{array}$ \\
\hline CKF 2011; 17 (65):14-17 & $\mathrm{OA}$ & $\mathrm{BSN}$ & $9 \mathrm{BSN}$ & 0 \\
\hline NEM 2014; 11 (1): & $\mathrm{OA}$ & $\mathrm{BSN}$ & $\begin{array}{c}1 \text { MS Professor } \\
1 \text { PhD Anthropology }\end{array}$ & 6 (6 book chapters) \\
\hline NEM 2014; 11 (1): & $\mathrm{OA}$ & BSN & $\begin{array}{c}4 \text { BSN } \\
1 \mathrm{PhD} \text { Anthropology }\end{array}$ & $\begin{array}{l}7 \text { ( } 1 \text { review article, } \\
5 \text { book chapters, } \\
1 \text { web resource) }\end{array}$ \\
\hline Total & OA 13 & $\begin{array}{c}\text { BSN 12 } \\
\text { PhD } \\
\text { Anthropology } 1\end{array}$ & $\begin{array}{c}25 \text { BSN } \\
1 \text { PhD Anthropology } \\
4 \text { MS Professor } \\
2 \text { MS Nurse }\end{array}$ & 86 \\
\hline
\end{tabular}

BSN = Bachelor of Science in Nursing; MD = Medical Doctor; BA = baccalaureate; MS = Master of Science; PhD = Doctor of Philosophy; $\mathrm{OA}=$ original article; CJFHP = Croatian Journal for Public Health (ISSN 1845-3082); CKF = Child, Kindergarten, Family (ISSN 13311948); NEM = Nursing Education Magazine (ISSN 1334-7551)

and six were from other specialties (anthropology, education and philosophy). All 35 articles were authored by at least one author from UNIDU, as well as 3 single-author articles. Of all co-authors, academic appointment title was listed by three co-authors, of which one had the highest scientific rank and two were research fellows. Only two nurses with graduate education possessed an academic appointment title.
Author structure and number of co-authors are shown in Table 4.

\section{Analysis of references}

According to HRČAK, out of 35 articles there was 1 without references and a total of 303 references were used in 34 articles. The structure of references was as 
Table 4. Author structure and number and level of coauthor education

\begin{tabular}{|l|c|}
\hline Author structure & Number \\
\hline BSN students & 66 \\
MD, PhD & 3 \\
BA Health Education & 1 \\
BA Psychology & 1 \\
AD Nurse & 10 \\
PhD Nurse & 1 \\
PhD Anthropology & 4 \\
Professor Public Health & 5 \\
MS Professor & 2 \\
MS Nurse & 2 \\
Total number of authors & 95 \\
\hline
\end{tabular}

BSN = Bachelor of Science in Nursing; $\mathrm{MD}=$ Medical Doctor BA = baccalaureate MS = Master of Science $\mathrm{PhD}=$ Doctor of Philosophy; AD = Associate Degree in Nursing

follows: 157 book chapters (85 Croatian, 45 English and 1 Slovenian), 80 original articles (45 English and 18 Croatian), 16 review articles (English), 9 brief communications (English), $7 \mathrm{PhD}$ theses (Croatian), and 41 web sources (English). None of the references was used twice. The relationship of English and Croatian references cited was 168 vs. 118.

\section{Analysis of article volume}

Overall structure of article type was as follows: 24 technical (professional) articles, 5 research (scientific) articles and 6 brief communications. Interestingly, there was no review article. Nevertheless, we found the

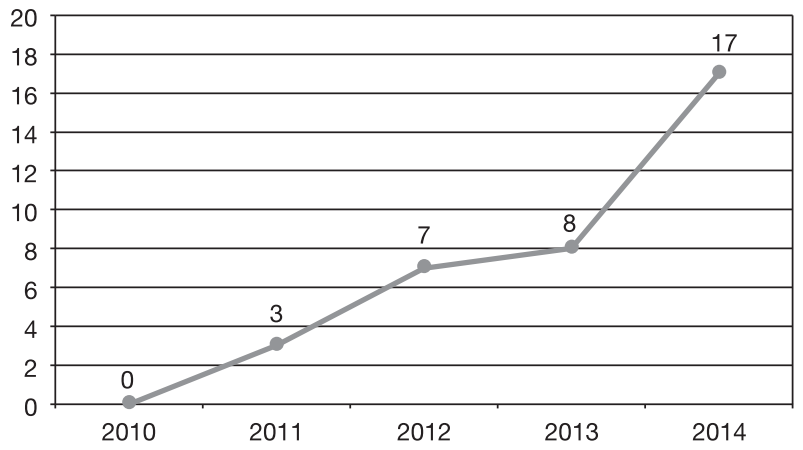

Fig. 1. Number of articles written by University of Dubrovnik Bachelor of Science in Nursing students and published during the 2010-2014 period. percentage of technical articles to have gradually decreased, while the share of research articles was slowly increasing during the 5-year period. Study results showed that scientific productivity of UNIDU BSN students before the introduction of scientific writing as mandatory course in the BSN program was zero. After the course had been introduced in 2010, the number of published articles increased by $133 \%$ in the academic year 2011-1012, by $14 \%$ in the academic year 2012 2013 , and by $113 \%$ in the academic year $2013-2014$ (Fig. 1).

\section{Discussion}

Bibliometric research should represent an exact fundamental for comparison of certain scientific communities, but it is often that, in an attempt to compare the results, problems arise due to the fact that different variations of databases are being used. Our database search yielded 60 addresses, 48 of these definitely confirmed to represent UNIDU. Analysis showed that many articles failed to follow the principle of hierarchy in the address structure (university, institution, and department). Some addresses were incomplete, lacking one or two elements of the structure. If we want to increase visibility in the global scientific literature, we must pay more attention to formal identification of the authors, institutions, university and country.

Analysis of the number of articles per year and article type showed the number of articles to have increased since 2010. It can be supposed that it was caused by introducing scientific writing as mandatory course in the BSN study program. In 1997, the Ministry of Science and Technology of the Republic of Croatia issued the Minimal Conditions for Election in the Scientific Vocations (Official Gazette 38/97) ${ }^{16}$. There are two basic criteria for evaluation: an article published in a journal with international peer-review and indexation of the journal, i.e. article indexed in Current Contents and/or other bibliographic databases. Since this regulation moves the importance from the quantity to the quality, we do hope that we shall witness further increase in the number of articles published in domestic and international journals.

The share of papers published in Croatian language was $100 \%$. Analysis of the journals showed that 35 articles were published in 4 journals, most of them in 
SG/NJ (22 articles, 39.9\%). In our opinion, the reasons were lacking familiarity of work with editorial manager submission software and easier correspondence with editorial offices of domestic journals indexed in global secondary databases.

The main objective of the study course is that students must publish at least one scientific article in a Croatian or preferably in international scientific journal. The main reason for such approach is that each student must strive to reach the criteria for further studies at $\mathrm{MSN}$ and $\mathrm{PhD}$ degree programs ${ }^{17,18}$.

For better understanding of the outlined approach, it is necessary to present results from the previously conducted research by Sambunjak et al. ${ }^{19}$. The findings reported by this group of authors from Split, according to which clinical guidelines, narrative review articles and translations of valuable articles from the world literature are the preferred contents of scientific biomedical journals published in Croatian language, were not confirmed by our analysis. Namely, the articles published in the four investigated journals represented in the local database HRČAK for years, made up 100\% of papers published in Croatian language, including $31 \%$ of original scientific papers, $25 \%$ of clinical observations, no reviews, and $10 \%$ of brief communications.

During the study period, the total number of published articles was 644. The articles published by BSN candidates in the Croatian Journal for Public Health (CJFHP) accounted for 4\%, in the Child, Kindergarten, Family (CKF) 2\%, in Nursing Education Magazine (NEM) 10\%, and in Sestrinski glasnik/Nursing Journal (SG/NJ) 7\% of all published articles.

If we want to increase visibility in the global scientific literature, we must pay more attention to formal identification of the authors, institutions and universities.

The mean number of published articles slightly grew from 2010 to 2014. It can be supposed that it was to a great extent owing to the introduction of mandatory course teaching skills of scientific writing in the last year of the study program.

Analysis of each article showed frequent co-authorship within the University of Dubrovnik (12 articles, 34\%), and somewhat more often with authors from other Croatian institutions (23 articles, 66\%).

Some notes may prove helpful for future investigations. Special attention should be paid to the specific Croatian system of person identification (mostly women) with two family names that are too often cited in a wrong way.

The presented results on scientific productivity of the UNIDU BSN students could be compared with the results of other universities in the world, as well as with other Croatian institutions, in order to find new approaches to upgrade awareness of the importance of scientific writing. Future investigations should bear in mind that nursing original research papers published in Croatian language must not become an anachronism ${ }^{1}$. The importance of scientific communication in mother tongue, because of the inflow of information in the system of nursing education and for their flow through the local communities of health care system, should not contribute to the process of marginalization of publishing in mother tongue versus English language.

At the same time, the Croatian scientific nursing community must make big steps to increase scientific productivity at the international level in order to increase international visibility of the Croatian nursing authors.

\section{References}

1. Vičić Hudorović V, Hudorović N. Nursing community in Croatia and academic writing: a continuous challenge. Croat Med J. 2013;54(5):504. doi: 10.3325/cmj.2013.54.504

2. Davies E. Reflective practice: a focus for caring. J Nurs Educ. 1995;34:167-74.

3. Fakude LP, Bruce JC. Journaling: a quasi-experimental study of student nurses' reflective learning ability. Curationis. 2003;26: 49-55.

4. Ibarreta GI, McLeod L. Thinking aloud on paper: an experience in journal writing. J Nurs Educ. 2004;43:134-7.

5. Kessler PD, Lund CH. Reflective journaling: developing an online journal for distance education. Nurse Educ. 2004;29: 20-4.

6. Tryssenaar J. Interactive journals: an educational strategy to promote reflection. Am J Occup Ther. 1995;49:695-702.

7. Riley-Doucet C, Wilson S. A three-step method of self-reflection using reflective journal writing. J Adv Nurs. 1997;25: 964-8.

8. Williams RM, Wessel J, Gemus M, Foster-Seargeant F. Journal writing to promote reflection by physical therapy students during clinical placements. Physiother Theory Pract. 2002;18: 5-15.

9. Wong FKY, Kember D, Chung LYF, Yan L. Assessing the level of student reflection from reflective journals. J Adv Nurs. 1995;22:48-57. 
10. Wong FYK, Loke AY, Wong M, Tse H, Kan E, Kember D. An action research study into the development of nurses as reflective practitioners. J Nurs Educ. 1997;36:476-81.

11. Dornik E, Vidmar G, Žumer M. Nursing education in Slovenia and its impact on nurses publishing in their professional journal. Nurse Education Today. 2005;25:197-203. doi: 10.1016/j.nedt.2005.01.005

12. Hebrang Grgić I. Scholarly journals at the periphery: the case of Croatia. Learned Publishing. 2014;27(1):15-20. doi: $10.1087 / 20140103$

13. Gasparyan AY. Editing Croatian scholarly journals: achievements and challenges. European Science Editing. 2014;40 (2):30.

14. Maina S. Hrčak: the portal for Croatian scientific journals. European Science Editing. 2014;40(2):45.
15. Popescu II. (homepage on the Internet). Bucharest: I.I. Popescu; 2002. Scientific journal ranking by average impact factors; (about 20 screens). Available at: http://www.geocities.com/ iipopescu/IOANIOVITZ_POPESCU.html. retrieved in 2014

16. Narodne novine (homepage on the Internet). Zagreb: Narodne novine d.d. (cited 2006 Jul 28). Available at: http://www.nn.hr/ sluzbeni-list/index.asp. retreived in 2014

17. Bekavac A, Petrak J, Buneta Z. Citation behavior and place of publication in the authors from the scientific periphery: a matter of quality. Inf Process Manag. 1994;30:33-42.

18. Green SG, Baue TN. Supervisory mentoring by advisers: relationships with doctoral student potential, productivity, and commitment. Pers Psychol. 1995;48(3):537-61.

19. Sambunjak D, Huić M, Hren D, Katić, M, Marušić A, Marušić M. National vs. international journals: views of medical professionals in Croatia. Learn Publ. 2009;22:57-70.

\section{Sažetak \\ POPULARIZACIJIA ZNANSTVENOG PISANJA UVOĐENJEM OBVEZNOG KOLEGIJA U CURRICULUM PREDDIPLOMSKOG STUDIJA SESTRINSTVA - ISKUSTVA SVEUČILIŠTA U DUBROVNIKU, HRVATSKA}

\section{Zidarić, V.Vičic-Hudorović i N. Hudorović}

Jedna od metoda koja je u uporabi za povećanje stupnja znanstvene vidljivosti studenta je usvajanje vještina publiciranja znanstvenih radova. Svrha je bila istražiti stupanj učinkovitosti uvođenja obveznog kolegija u preddiplomski studijski program sestrinstva Sveučilišta u Dubrovniku, a kojega je osnovni cilj usvajanje znanja i praktičnih vještina znanstvenog pisanja i publiciranja u populaciji studenata prvostupnika sestrinstva te kako kolegij utječe na povećanje obima publiciranja. Učinjena je pretraga portala znanstvenih časopisa Republike Hrvatske naziva HRČAK. Učinjena je pretraga prema prezimenu autora članaka koji su danom publiciranja bili studenti preddiplomskog studija sestrinstva Sveučilištu u Dubrovniku i to u razdoblju od 2010. do 2014. godine. Svi objavljeni članci bili su publicirani na hrvatskom jeziku u znanstveno-stručnim časopisima koji se izdaju u Republici Hrvatskoj. Iznalazi se da je 66 studenata objavilo 35 članaka, i to samostalno ili u suradnji s koautorima. Dva (6\%) članka objavio je jedan autor. Među koautorima najviše je bilo onih sa završenim diplomskim ili sveučilišnim studijem sestrinstva (20\%), a slijede liječnici i antropolozi (25\%). Ukupan broj autora iznosi 95, a udio radova publiciranih na hrvatskom jeziku iznosi 100\%. Iznalazi se značajno povećanje broja publiciranih članaka od 2012. do 2013. godine, i to za 14\%, a od 2013. do 2014. godine za 113\%. U svrhu povećanja znanstvene produktivnosti populacije studenata sestrinstva potrebno je u studijske programe uvrstiti nove metode i kolegije koji trebaju povećati stupanj zainteresiranosti studenata za publiciranje, i to osobito na engleskom jeziku, tj.jeziku svjetske znanstvene zajednice. Da bi se povećala međunarodna znanstvena vidljivost studenata sestrinstva članovi akademske hrvatske sestrinske znanstvene zajednice trebaju uvrstiti dodatne kolegije u svrhu boljeg pojašnjenja korisnosti povećanja znanstvene produktivnosti članova hrvatske sestrinske akademske zajednice.

Ključne riječi: Znanstveno-istraživački rad; Pisanje; Sestrinstvo-edukacija; Publikacije; Edukacija sestara, prvostupnici; Baze podataka kao predmet; Hrvatska 